\title{
КУЛЬТУРНАЯ АНТРОПОЛОГИЯ
}

\author{
А. А. Слезин
}

\section{Комсомол и молодежная печать в период ранней «оттепели» ${ }^{1}$}

Слезин Анатолий Анатольевич доктор исторических наук, профессор, Тамбовский государственный технический университет (Тамбов, Россия)
Внимание к печати 1950-х гг. в отечественной исторической науке последних десятилетий связано прежде всего с изучением освобождения общественного сознания от сталинского наследия и мобилизации населения на реализацию планов социально-экономической модернизации советского типа. Появился ряд диссертаций, которые в этой связи изучали и роль молодежной печати 1950-х гг.2 Однако при этом авторы стыдливо старались обойти тему влияния на печать комсомола, который в советской историографии однозначно подавался как умелый организатор и вдохновитель советской молодежной печати. В данной статье, отбрасывая стереотипы прежних лет, мы пытаемся с современных позиций охарактеризовать стиль взаимоотношений комсомола и молодежных изданий середины и конца 1950-х гг. Главное внимание автор направил на исследование практики воплощения в жизнь решений комсомольских органов, реакции на них работников СМИ и общества. Нормативная база взаимоотношений комсомола и органов печати в основном анализировалась с помощью «Сборников постановлений», которые распространялись под грифом «Совершенно секретно» в республиканских и областных комитетах ВЛКСМ. Сегодня они сохранились в считаных экземплярах в ряде архивохранилищ и частных коллекций. 
Изучение социокультурного феномена комсомола с позиций историзма и объективности полезно не только с точки зрения формирования механизма и основных направлений молодежной политики в Российской Федерации, но и для более глубокого понимания социально-политических процессов в советском государстве на одном из переломных этапов его развития.

Печать играла огромную роль в развертывании идейно-воспитательной деятельности комсомола. К началу 1957 г. ВЛКСМ имел 64 печатных издания, общий разовый тираж которых составлял 13 млн экз. ${ }^{3}$

«Довести партийные и молодежные газеты и журналы до каждого юноши и девушки, умело пропагандировать и распространять их - важная задача комсомольских организаций», - подчеркивал ЦК ВЛКСМ в Постановлении от 25 сентября 1959 г. ${ }^{4}$ Кампании по организации подписки на периодические издания рассматривались в связи с этим как важнейшие политико-массовые акции. Была налажена систематическая работа с кадрами общественных распространителей печати, организована их учеба. Для пропаганды молодежных газет и журналов широко использовались читательские конференции, обсуждения отдельных материалов, выставки, светогазеты. Организовывались книжно-журнальные базары. Лучшие распространители печати награждались почетными грамотами. На улицах, в клубах, библиотеках, в парках устанавливались газетно-журнальные витрины (нередко изготовленные комсомольцами своими руками). Использовался также принцип «добровольно-принудительного» распространения печатных изданий (хотя официально провозглашалась необходимость строгого соблюдения принципа добровольности при проведении подписки ${ }^{5}$.

Однако и в таких условиях не только рядовые комсомольцы, но и активисты не очень охотно подписывались на молодежные издания. Так, в 1959 г. в Мордовской АССР журнал «Молодой коммунист» выписывали только 129 чел., журнал «Комсомольская жизнь» - 153 чел., хотя в Республике насчитывалось более 1,5 тыс. секретарей комсомольских организаций, свыше 150 штатных комсомольских работников ${ }^{6}$. В Мурманской области в некоторых районах не оказалось ни одного индивидуального подписчика на журналы «Молодой коммунист» и «Молодая гвардия» 7.

ЦК ВЛКСМ неоднократно рассматривал вопросы деятельности комсомольско-молодежной печати. От молодежных изданий требовали отражать действительную жизнь комсомольских организаций, политическую и трудовую активность молодежи, раскрывать опыт работы комитетов комсомола8. Важнейшим принципом советской печати был провозглашен принцип «писать правдиво» ${ }^{9}$. Были озвучены и аргументы в пользу дискуссий на страницах печати: «Невысказанные мысли, сомнения все равно обсуждаются на улице, в аудиториях вузов, школ, дома, в общежитии, но только уже без идейного влияния комсомольской организации»10. Показательно, что публично осуждались методы фальсификации, применявшиеся некоторыми изданиями для подготовки материалов ${ }^{11}$.

Используя образ чеховского отставного унтера Пришибеева, привнесшего в гражданскую жизнь обывателей дух казармы, слежки и запретов, «унтер-пришибеевской философией» назвала «Комсомольская правда» стремления на комсомольских собраниях обсуждать слишком общие или несущественные вопросы ${ }^{12}$. 
В отличие от прежних лет, после XX съезда КПСС в тамбовской комсомольско-молодежной газете можно было прочитать: «На самом деле говорим о новом, а ничего нового не делаем. Говорим о борьбе с начетничеством и догматизмам, а сами их насаждаем. Говорим об инициативе, а на самом деле ее сковываем». И в том же номере: «Связь с жизнью... Настолько эти слова стерлись, как говорится, ошаблонились, что на них в последнее время и внимания не обращают» ${ }^{13}$.

Любопытно, что несанкционированные митинги окололитературной молодежи на площади Маяковского в Москве были фактически одобрены «Комсомольской правдой». Более того, защищая организацию подобного московскому публичного чтения стихов в Тамбове, «Комсомолка» подвергла критике постановление бюро Тамбовского городского комитета ВЛКСМ об исключении из союза тамбовского комсомольца Гогина за «организацию сборищ для пропаганды низкопробной поэзии» ${ }^{14}$.

Вместе с тем, как и в прежние годы, «правдивость» понималась часто весьма субъективно. ЦК ВЛКСМ подверг «Комсомольскую правду» суровой критике за поддержку «маяковки» ${ }^{15}$. Отдел пропаганды и агитации ЦК ВЛКСМ подчеркивал: «Наша идеология - это не рынок идей, где предоставляется право выставлять любую концепцию или систему взглядов. Есть один рубеж, отделяющий диспут от пустой болтовни, это - марксистско-ленинская методология» 16 .

Комсомольские органы считали себя вполне правомочными осуществлять функции цензуры. Обком ВЛКСМ Еврейской Автономной области призвал в конце апреля 1956 г. усилить контроль за выпуском стенных газет ${ }^{17} .24$ декабря 1957 г. было принято Постановление ЦК ВЛКСМ «О романе Н. Зеленского “Поле чести"», в котором критически оценивались не только роман, но и рецензии на него ${ }^{18}$. В Тюмени обком ВЛКСМ принял разгромное Постановление по поводу кинообозрения «На экранах Тюмени» в газете «Тюменский комсомолец». Оценка вышедших на экран кинофильмов была названа ошибочной и дезориентирующей молодежь ${ }^{19}$.

В Архангельске внештатный корреспондент местной молодежной газеты предложил совместить лекции с более свободными формами изучения идейного наследия, например, с номерами художественной самодеятельности ${ }^{20}$. Хотя в опубликованных в ходе газетной дискуссии материалах в основном выражалось несогласие с данной позицией, а подобные формы работы широко использовались в деятельности комсомольских агитбригад, публикацию расценили как очернительство действительности. Она стала поводом для обновления состава редакции 21.

Впрочем, отношения комсомольских органов с органами печати отнюдь не ограничивались функциями контроля. Так, бюро Тюменского обкома ВЛКСМ не реже одного раза в квартал рассматривало обзор материалов областной молодежной газеты. Секретарям обкома ВЛКСМ было вменено в обязанности знакомить сотрудников редакции с главными проблемами в работе комсомольских организаций 22 . На заседаниях комитетов ВЛКСМ всех уровней комсомольским руководителям рекомендовалось регулярно самим выступать в комсомольской печати. Но лишь некоторым из них это было по силам. По воспоминаниям журналиста И. И. Бяхова, «редакции, как правило, сами отказывались от статей номенклатурных графоманов, повторяющих общеизвестные вещи» 23 . 
В обязанность редакций комсомольско-молодежных изданий включили пропаганду марксистско-ленинской теории, ориентируя на то, чтобы тесно увязывать ее с конкретными задачами молодежи, постоянно разъяснять молодежи внутреннюю и внешнюю политику КПСС, мобилизовывать юношей и девушек на претворение этой политики в жизнь, остро критиковать недостатки в воспитательной работе среди молодежи, больше публиковать материалы на моральные темы ${ }^{24}$.

Комитеты ВЛКСМ регулярно рассматривали вопросы о работе по рассмотрению жалоб и писем в редакциях комсомольско-молодежных газет. Ответы авторам на их письма предписывалось давать не позже чем через 10-15 дней. Не отвечавших на запросы нерадивых комсомольских функционеров редакторам разрешалось критиковать напрямую через газеты. По утверждению современного историка В.А. Ванина, «именно газету рядовые комсомольцы воспринимали как самый эффективный комсомольский орган, который может всерьез повлиять на любое учреждение, любого бюрократа» ${ }^{25}$.

Разумеется, не все письма публиковались. Однако информация, содержавшаяся в неопубликованных письмах, использовалась как повод для творческих командировок, как материал для анализа специфики общественного мнения.

В изучаемый период ярко проявилось недовольство молодых читателей частым использованием псевдонимов. Статьи без подписей все чаще называли анонимками. Показателен факт из истории тамбовской областной организации ВЛКСМ: в январе 1958 г. делегаты областной конференции единодушно проголосовали за то, чтобы председательствующему на записки без подписей не отвечать ${ }^{26}$.

Симптоматично, что ЦК ВЛКСМ заботился об учете интересов молодежной и детской аудитории. Корреспонденты ориентировались на нахождение в рабочее время преимущественно в пионерских и комсомольских организациях. Комсомольское руководство было обеспокоено тем, что «в материалах общественно-политического характера исторические факты, события даются часто без показа образов и поступков людей», «некоторые статьи о Родине и Коммунистической партии написаны сухо» ${ }^{27}$. Весьма критично оценивалась «Пионерская правда»: «В выборе тем, в языке и стиле ряда статей и корреспонденций много шаблона, однообразия, в верстке и оформлении номеров газеты недостаточно выдумки. В газете мало фельетонов, басен, карикатур, затей. Это сушит газету, снижает ее воспитательное значение» ${ }^{28}$.

Причины недостатков «Пионерской правды» объяснялись в первую очередь тем, что редколлегия газеты слабо связана со школами, пионерскими организациями и пионерским активом ${ }^{29}$. От газеты ждали поиска и поддержки новых форм и методов работы пионерских организаций ${ }^{30}$.

И надо признать, что комсомольско-молодежная и пионерская печать меняла свой облик. На страницах газеты «Пионерская правда» проводились заочные слеты, перекличка дружин по обмену опытом работы, популяризировались увлекательные игры, соревнования, конкурсы. Газета становилась более веселой. Публиковала фельетоны, басни, рассказы в картинках, карикатуры, песни, пьесы для художественной самодеятельности. В материалах было все меньше штампов, проявлялось все больше выдумки в оформлении номеров. 
Во второй половине 1950-х гг. комсомольско-молодежные издания стали чаще публиковать беседы агитаторов, ответы на вопросы читателей, консультации, статьи и лекции по теоретическим вопросам. Пропагандистские материалы стали подаваться под привлекающими, броскими заголовками, снабжаться диаграммами, фотоснимками, картами, схемами. Согласимся с известной исследовательницей К. Уль (имея в виду и другие молодежные издания): «Дискурс, который формировался и распространялся "Комсомольской правдой" и официальными документами, функционировал в качестве основного канала, определявшего мировоззрение молодежи, широкий спектр разнообразных влияний оформлял и изменял эту насаждавшуюся государством риторику» 31.

Большинство молодежных газет открыли на своих страницах заочные семинары, школы по вопросам конкретной экономики. Вместе с тем отдел пропаганды ЦК ВЛКСМ признавал в 1958 г., что уровень пропагандистских и теоретических материалов во многих газетах не отвечает растущим запросам молодого читателя. Они нередко скучно пересказывают известные истины, не будят творческую мысль, содержание их не связывается с актуальными проблемами современности ${ }^{32}$.

Нельзя забывать, что политическая культура журналистов проявлялась не только в политических идеях, которые они преподносили читателям, но и в характере даваемых ими оценок и прогнозов социальной действительности, в поддержке или критике участников политического процесса, в методах анализа и интерпретации информации.

Деятельность средств массовой информации в те годы не мыслилась без пропаганды коммунистических идей, а журналистика представлялась одним из главных орудий пропагандистского воздействия.

Ценностные социальные установки в структуре личности журналиста по-прежнему рассматривались упрощенно. Только если в начале периода они преподносились как служение общепролетарскому делу, то с конца 1950-х гг. все настойчивее говорилось о служении делу строительства коммунизма.

Говоря о журналистике, Н. С. Хрущев нередко использовал военную лексику: «Печать - главное наше идейное оружие. Она призвана разить врагов рабочего класса, врагов трудящихся. Как армия не может воевать без оружия, так и партия не может успешно вести свою идеологическую работу без такого острого и боевого оружия, как печать»з3. На приеме в Кремле в честь Первого Всесоюзного съезда советских журналистов Н. С. Хрущев назвал журналистов «подручными партии»: «Почему подручные? Потому что вы действительно всегда у партии под рукой. Как только какое-нибудь решение надо разъяснить и осуществить, мы обращаемся к вам, и вы, как самый верный приводной ремень, берете решение партии и несете его в самую гущу нашего народа» ${ }^{34}$.

Вместе с тем, скорее всего, прав современный исследователь В.А. Беляев, отметивший следующую особенность советских журналистов изучаемого периода: «подручные партии, но сочувствующие массам». Среди армии «прирученной» интеллигенции журналисты, по мнению В. А. Беляева, едва ли были самыми доверенными лицами, так как по роду своей профессии и образу мыслей находились слишком близко к настроениям той части общества, которую называли народными массами. Именно из этой особенности он справедливо выводил причину 
перманентной конфронтации власти и журналистов, «которую можно объяснить враждебностью аппаратчиков к общественному интеллекту как к потенциальной угрозе»35.

Именно это порождало стремление руководства партийных организаций к установлению полного контроля над сотрудниками печатных органов.

Типично решение бюро Старо-Юрьевского райкома партии. Заслушав отчет редактора о работе газеты, в своем постановлении бюро записало: «Обязать редактора газеты все печатаемые статьи на партийные и сельскохозяйственные темы согласовывать с ответственными работниками РК КПСС или исполкома районного Совета депутатов трудящихся» ${ }^{36}$.

Разгромный характер имело Постановление ЦК ВЛКСМ от 23 июля 1958 г. «О серьезных недостатках в работе Чувашской областной газеты “Молодой коммунист”»37. Особенно досталось редакции за «путаные формулировки, неправильно истолковывающие отдельные положения марксистско-ленинской науки»38.

Орган ЦК ЛКСМ Белоруссии и Союза писателей БССР «Маладосцъ» подвергся острой критике и кадровому разгрому за выпячивание отрицательных сторон жизни послевоенного села ${ }^{39}$. Журнал «Пионер» был обвинен в показе советских детей черствыми, грубыми, неумными, в карикатурном изображении представителей старшего поколения ${ }^{40}$. А журнал «Молодой колхозник» критиковали за то, что «редко публикует популярно изложенные статьи или беседы о путях развития сельского хозяйства в семилетке, постепенном превращении сельскохозяйственного труда в разновидность труда индустриального»; «Публикуемые материалы нередко не обогащают представлений молодежи о земледелии как труде творческом, полном романтических поисков и свершений» ${ }^{41}$.

Вывод о политической незрелости работников газеты «Рязанский комсомолец» отдел пропаганды и агитации ЦК ВЛКСМ сделал на основании того факта, что в номерах этой газеты было помещено много материалов об убийствах, грабежах и прочих преступления ${ }^{42}$.

Стараясь расширить круг читателей, журнал «Смена» попытался разнообразить тематику своих номеров и был обвинен в «серьезных идеологических ошибках». ЦК ВЛКСМ обратил внимание отдела пропаганды и агитации на недостаточный контроль за работой редакций молодежных газет ${ }^{43}$.

Комсомольские идеологи были крайне недовольны тем, что в № 17 «Смены» за 1960 г. нет материалов, посвященных «героике нашего времени», зато опубликованы материалы, «изображающие нечестных людей и различных неудачников». Наиболее гневную реакцию комсомольского руководства вызвала статья А. Свободина «Двое пришли в искусство ${ }^{44}$. В рецензии на произведения молодых художников Юрия Коваля и Галины Эдельман не только сказаны слова одобрения, но и помещены репродукции картин, выполненные в модернистской манере. Пропагандой чуждых советским людям, советскому искусству теорий, выступлением против принципов искусства социалистического реализма ЦК ВЛКСМ называл эту статью, в которой автор посмел написать: «Конечно же, я не против преподавания основ изобразительного искусства, и любой, даже самый оригинальный художник обязан в совершенстве владеть техникой рисунка. Но как 
часто за многолетней обязательной студией тускнеет непохожесть дарования, и в результате выпускается еще один грамотный художник, не более?» 45

Довольно-таки точно характер газетных публикаций изучаемого периода, которые не вызывали возражений властных органов, отражают воспоминания о газете «Тагильский рабочий»: «Газетные полосы почти всецело были заполнены постановлениями и решениями ЦК партии... Плюс обязательные одобрительные отзывы трудящихся. Вбок от этих пространных, с длинными повторами текстов жмутся заметки о трудовых победах металлургов, горняков, дорожников, машиностроителей и даже банщиков. У всех трудовые победы - и никаких проблем, никаких огрехов... Язык суконный, масса канцеляризмов... Стихи, посвященные партии, родине, очередной пятилетке, практически ничего не меняли» ${ }^{46}$.

Но все же это не вся правда. Сегодня мы начинаем осознавать, что широкая моральная поддержка «потомственных» свинарок, доярок, пастухов, слесарей, токарей и иных передовиков производства имела положительные стороны. Проведенный нами опрос 100 ветеранов в Ставропольском крае, Воронежской, Тамбовской и Саратовской областях показал, что это считают одной из положительных черт комсомольско-молодежной печати большинство из них (67 из 100). «Читая подобные материалы, я понимал, что в повседневной жизни тоже есть место подвигу», - написал в анкете В.И. Фурсов из Воронежа. «В отличие от сегодняшних дней, когда мы постоянно слышим о “богатых, которые тоже плачут”, да о доблести “слуг народа" в правительстве и парламенте, мы чувствовали внимание к своей работе, ощущали заботу о нас. Правда, к сожалению, обычно только на словах», - заявил В.А. Щупленков (г. Ессентуки).

Именно в эти годы печать все более отражала реальность повседневной жизни, демонстрировала проблемные подходы к восприятию действительности.

ЦК комсомола требовал от комсомольско-молодежных изданий проявлять настойчивость в устранении вскрытых недостатков, а комсомольские организации нацеливал обязательно отвечать на критические выступления газет ${ }^{47}$. Показательны в этом отношении материалы заседаний Тюменского обкома ВЛКСМ. Им было отмечено «неправильное отношение к критике бюро Исетского райкома ВЛКСМ, выразившееся в признании неправильности статьи "Плоды неорганизованности" в газете "Тюменский комсомолец"». Бюро обкома ВЛКСМ обязало райком комсомола принять меры к устранению указанных в статье недостатков. Бюро Ханты-Мансийского окружкома ВЛКСМ обком обязал не только обсудить статью Омеличкина «Навести порядок в учете комсомольцев», но и принять конкретные меры по устранению отмеченных недостатков ${ }^{48}$.

О том, что юноши и девушки все в большей степени видели в комсомольско-молодежной печати доброго советчика, помощника и заступника, говорит заметный рост писем и обращений в редакции. Так, в 1957 г. в редакции тамбовской газеты «Комсомольское знамя» было зарегистрировано 3681 письмо (на 384 письма больше по сравнению с 1956 г.; опубликовано 1698 писем) ${ }^{49}$.

Так как некоторые журналисты в силу своего солидного возраста теряли интерес к молодежной теме, а порой просто не воспринимали проблемы, которые волнуют молодое поколение, проводя кадровую политику, комсомольские комитеты старались привлекать к работе в молодежных изданиях молодых журналистов. 
В 1960 г. около половины молодежных редакций составляли лица моложе 30 лет ${ }^{50}$. Приветствовалось привлечение к штатной работе бывших активных юнкоров, журналистов, пришедших в газеты с комсомольской работы.

В 1956 г. «Комсомольская правда» провела первый Всесоюзный слет юнкоров, Главный редактор газеты Д. Горюнов выступил с докладом «Разговор с друзьями газеты», в котором приоритетное внимание уделялось работе с письмами. В большинстве республик и областей слеты юнкоров стали в это время традиционными.

Постановление ЦК КПСС «О дальнейшем развитии общественных начал в советской печати и радио» (июнь 1960 г.) придало новый импульс развитию движения рабочих и сельских корреспондентов (в том числе юнкоров). Газеты и журналы старались шире использовать их в подготовке материалов к печати, привлекать к обсуждению планов редакций, проведению читательских конференций. В состав ряда редакций были введены молодые передовики и специалисты производства, комсомольские работники. Редакция газеты «Комсомолец Донбасса» впервые создала внештатные отделы (технического прогресса, молодежной самодеятельности, студенческой жизни, литературы и искусства, сатиры и юмора, информации, досуга) ${ }^{51}$. Развивая этот опыт, ЦК ВЛКСМ рекомендовал и другим редакциям комсомольских и пионерских газет создавать внештатные отделы, а также корреспондентские пункты, юнкоровские посты, советы редакций ${ }^{52}$.

Это способствовало массовости юнкоровского движения, активному развитию творческих способностей юношей и девушек, сотрудничавших с редакциями газет и журналов.

В то же время современная исследовательница рабселькоровского движения Р.В. Даутова справедливо отмечает: «Возможность писать о недостатках в республиканскую или центральную газету, на радио, независимо от мнения местного руководства, превращала рабселькоров в особую “касту”, которая как бы находилась "над” происходящим. У этих людей постепенно складывалась иллюзия своей особости, особого положения»53.

Деятельность внештатного корреспондента вполне могла стать первой ступенькой в дальнейшей карьере. В 1960 г. ЦК ВЛКСМ прямо рекомендовал редакциям молодежных газет и местным комитетам комсомола «лучше использовать постановление Совета Министров СССР от 28 мая 1958 г. № 581 "О частичном изменении порядка приема в высшие учебные заведения СССР”, активнее рекомендовать на учебу в университеты лучших производственников, хорошо проявивших себя в качестве юнкоров ${ }^{54}$.

Нельзя забывать, что большую роль в политической культуре журналиста играет выбор художественных и языковых средств. В связи с этим обратим внимание на то, что именно «Комсомольская правда» стала изданием, смело использующим новаторские формы подачи материала. Практически в каждом ее номере публиковались письма рядовых читателей (то подборкой, то самостоятельно, с комментариями и без них). Рубрики «Отклики и реплики», «По следам выступлений», «Командировка по тревожному письму», «Здравствуйте! С Вами говорит КП», «Клуб открыт, входите!» сближали газету с читателями, демонстрировали неравнодушие главной комсомольской газеты к их проблемам. 
Секретарь ЦК ВЛКСМ В. Е. Семичастный вспоминал: «Полистайте "Комсомолку" тех лет. "Вопросы к министру" (так называли рубрику) занимали в газете целые полосы. Почему не хватает общежитий на стройках, куда мы послали молодежь, почему квалификацию, разрядность не повышают вовремя, почему заработки низкие - целые серии “почему?". И министры обязаны были ответить»55.

Более частое использование жанра интервью в конце 1950-х гг. современными исследователями объясняется тем, что «оттепель породила интерес к личности, ее заботам, проблемам, в то время как журналистика сталинской эпохи воспевала прежде всего коллективный труд ${ }^{56}$.

В центре внимания комсомольско-молодежной печати все чаще становились обычные, на первый взгляд малопримечательные люди. Комсомольско-молодежная печать часто публиковала очерки о юношах и девушках, которые, окончив школу, пошли работать в колхозы и совхозы, стали квалифицированными специалистами.

Огромную роль в выдвижении на первый план темы маленького человека гражданина, любящего свою маленькую родину, ответственного за судьбы близких, сыграли очерки В. М. Пескова, работавшего в 1953-1955 гг. в газете «Молодой коммунар» (Воронеж), а затем ставшего корреспондентом «Комсомольской правды».

Активно ставился вопрос о строительстве новых клубов, кинотеатров, новых формах организации досуга молодежи.

С широким привлечением аудитории обсуждались вопросы нравственного выбора человека. Журнал «Юность», например, развернул в 1958 г. дискуссию «В чем счастье?». Неприметное на первый взгляд письмо читателя В. Прошина ${ }^{57}$ стала поводом к бурным спорам о смысле жизни ${ }^{58}$.

Утверждение полемического стиля становилось яркой приметой молодежной печати. Во многом этому послужила деятельность на посту главного редактора «Комсомольской правды» (1957-1959 гг.) А. И. Аджубея. «Передовицы» (передовые статьи) заменялись информационными и аналитическими корреспонденциями. В конце жизни А. И. Аджубей, сделавший главную комсомольскую газету интересной и «незаштампованной», говорил: «Мне очень хотелось бы, чтобы мы вообще ушли от криков - “долой”. Ибо применительно к журналистике подобный нигилизм не сулит ничего, кроме позорного появления на журнальном рынке бульварщины, пошлости, нравственного беспредела» 59 .

Весной 1960 г. при газете «Комсомольская правда» начал работать Институт общественного мнения под руководством Б. А. Грушина - первый в истории страны исследовательский центр, проводивший массовые опросы населенияб0. Симптоматично, что в начале акции провозглашалось: «С его помощью газета намерена изучать и рассказывать о мнении советских людей по наиболее актуальным вопросам внутренней и внешней политики СССР, коммунистического воспитания трудящихся»61.

Вновь (как когда-то в первые годы советской власти) бурно развивались стенные газеты. Резко выросла их критическая направленность. Так, комсомольскими организациями Кемеровской области в 1957 г. было выпущено 800 различных сатирических газет ${ }^{62}$. Газеты выпускались как в одном, так и в нескольких экземплярах, рукописные, отпечатанные на пишущей машинке и даже меловые 
(их писали ежедневно мелом на досках). Модными стали газеты к праздникам, фотоокна, световые, меловые, кино- и радиогазеты.

К концу 1950-х гг. в стране издавались десятки тысяч комсомольских сатирических газет: «Крокодилы», «Колючки», «Осы», «Иглы», «фотообвинения», «телевизоры» и т. п. В колхозе им. Жданова Малоярославецкого района Калужской области, например, популярностью пользовалась газета «Еж». На «Доске комсомольского штаба» Минского автозавода ежедневно обновлялись подготовленные по материалам комсомольских контрольных постов публикации в «окне сатиры»б3.

Роль цензоров на местах пытались играть комитеты партии и комсомола. Показателен пример из истории троллейбусного депо Тамбова, где выпускали сатирическую газету «Колючка». В 1958 г. в ней раскритиковали кассира депо за опоздание. Она расплакалась и побежала жаловаться секретарю парторганизации, который дал указание газету снять. Не помогли обращения комсомольцев в райком ВЛКСМ: «замкнули газету на ключ» 44 .

Однако, как правило, даже подобные меры не останавливали стенгазетчиков. Комсомольские газеты не боялись «испортить отношения» с теми или иными работниками, независимо от их ранга, редколлегии называли конкретных «носителей зла».

Вместе с тем комсомольские издания (особенно в конце 1950-х гг.) стремились широко показывать честные и благородные поступки юношей и девушек, рассказывать о положительном опыте. Практика выявила, что и сатирической печати не вредит публикация положительных материалов, воспитание молодежи на положительных примерах. Читатели, как правило, с интересом встречали шуточные «телеграммы», поздравления, дружеские шаржи, эпиграммы.

Нередко комсомольские стенные издания размещались в многолюдных местах: кинотеатрах, парках, клубах. Проходили выставки стенгазет. Это еще больше привлекало внимание к «малой» печати.

Интересно, что выпускались специальные пособия для редакторов стенной печати. Их наставляли: нельзя оскорблять, нельзя зубоскалить. Тем не менее в условиях, когда многие стороны частной жизни подвергались излишнему публичному контролю, авторы часто переходили допустимую грань, критика превращалась в унижение. Так, газета «Крокодил» московской фабрики «Парижская коммуна» поместила карикатуру на молодую работницу, которая однажды насорила в цехе, в виде утопающей в грязи свиньи с указанием имени и фамилии 65 .

Увлекшись изобличением пьяниц и хулиганов, некоторые молодежные издания иногда как бы не замечали проявления рваческих настроений, демагогии, клеветы и взяточничества.

Правда, к чести комсомольского руководства, ЦК ВЛКСМ и местные комитеты комсомола, как правило, выступали против смакования недостатков, размещения пошлых и безграмотных текстов, оскорбительных рисунков, превращения сатирических газет из средства воспитания в своеобразные «позорные столбы». В комсомоле осознали, что, разговаривая с провинившимися юношами и девушками грубым, оскорбительным тоном, можно вызвать вместо раскаяния чувства раздражения и озлобления. 
ЦК комсомола призывал печать «острее выступать против бесхозяйственности, лодырей, консерваторов, глушителей критики, краснобаев, зажимщиков полезных предложений рационализаторов и изобретателей»66.

Следует признать положительным введение в практику работы комитетов комсомола обсуждение наиболее важных, принципиальных материалов и принятие практических мер по устранению вскрытых в печати недостатков.

Как ни странно прозвучит, но именно комсомольская мода на стенные газеты способствовала столь уникальному явлению в отечественной истории, как самиздат. Многие самиздатовцы-диссиденты 1950-х гг. и последующих лет бывшие комсомольцы, разочарованные советской действительностью. Некоторые самиздатовские издания сначала были обыкновенными стенгазетами, но вышли из-под контроля партийных и комсомольских органов. Из ВЛКСМ были исключены создатели самиздатовских журналов Л. Бородин (Иркутский государственный университет), В. Герчиков (Новосибирский завод «Сиблитмаш»), Е. Попов (Красноярск $)^{67}$. Другие самиздатовские издания появились в качестве противовеса комсомольским газетам. Так, в 1956 г. в Тамбовской области распространялась самиздатовская газета, которая откровенно противопоставляла себя комсомольскому сатирическому выпуску «Кипяток»: «Но от него имеется отличье, / Которое огромно, велико. / Во-первых, нет того величья, / Не задираем нос так высоко»68.

Таким образом, влияние комсомола на печать в середине и конце 1950-х гг. было отнюдь не однозначным. Во многом способствуя развитию юнкоровского движения, стенной печати, новаторских подходов к формированию содержания газет и журналов, комсомол тем не менее одновременно и сдерживал процесс расширения гласности. «Оттепель» и в данной сфере уже на начальном своем этапе ярко проявила свою противоречивость. Переориентировать общественное мнение на пристальное внимание к своим изданиям комсомолу не удалось. Тем не менее надо признать, что в изучаемый период комсомол много сделал для «интеллектуального пробуждения» молодежи. Он боролся не только за количество, но и за качество печатного слова. Внедряемые в практику художественные и языковые средства вызывали рост интереса юношей и девушек к молодежным изданиям.

1 Исследование выполнено при поддержке РФФИ в рамках научно-исследовательского проекта № 15-31-01002 «а1» «Комсомол как социокультурный феномен XX века».

2 Кузнецов В.В. Роль печати в организации освоения целинных и залежных земель на Алтае, 1954-1960 гг.: дис. ... канд. ист. наук. Кемерово, 2000; Скорочкин Р. В. Местная печать в СССР 1953-1957 гг.: на материалах Тамбовской области: дис. ... канд. ист. наук. Тамбов, 2006; Корнева Л. Е. Общественно-политическая и культурная жизнь Западной Сибири в 1953 1964 гг. и ее отражение в периодической печати: дис. ... канд. ист. наук. Томск, 2006; и др.

3 Сборник постановлений ЦК ВЛКСМ (принятых после ХІІ съезда ВЛКСМ). М., 1958. C. 94 .

4 Постановление ЦК ВЛКСМ от 25 сентября 1959 г. «О мерах улучшения работы комсомольских организаций по распространению комсомольских и пионерских газет и журналов» // Сборник постановлений ЦК ВЛКСМ (январь 1958 г. — январь 1960 г.). М., 1960. С. 509.

5 Там же. С. 512.

6 Там же. С. 510. 
7 Там же. С. 511.

8 Там же. С. 226.

9 Постановление ЦК ВЛКСМ от 17 марта 1955 г. «О грубой ошибке, допущенной газетой “Смена" - орган Смоленского обкома ВЛКСМ» // Сборник постановлений ЦК ВЛКСМ (принятых после XII съезда ВЛКСМ). М., 1958. С. 195.

10 Российский государственный архив социально-политической истории (далее РГАСПИ). Ф.М-1. Оп. 32. Д.956. Л. 8.

11 Постановление ЦК ВЛКСМ от 17 марта 1955 г. С. 194-196.

12 Александрова Н. Об унтер-пришибеевых из Мариинского Посада // Комсомольская правда. 1956. 2 февр.

13 Что скажут другие пропагандисты // Комсомольское знамя. 1956. 26 окт.

14 Архипова Л. Двести «шалопаев» // Комсомольская правда. 1961. 1 окт.

15 Из протокола № 42 заседания Бюро ЦК ВЛКСМ // Поликовская Л.В. Мы предчувствие... предтеча...: Площадь Маяковского: 1958-1965. M., 1997. URL: http://www.memo.ru/ history/diss/books/mayak/index.htm (дата обращения: 01.02.2017).

16 РГАСПИ. Ф.М-6. Оп. 14. Д. 111. Л. 37-38.

17 Дриленко В.В. Молодежь Хабаровского края и власть в период «оттепели» 19531964 гг. // Гуманитарные и социальные науки. 2010. № 2. С. 41.

18 Сборник постановлений ЦК ВЛКСМ (принятых после ХІІ съезда ВЛКСМ). С. 421-422.

19 Архивная история газеты «Тюменский комсомолец». URL: http://media.utmn.ru/library_ view_book.php?chapter_num=26\&bid=840 (дата обращения: 02.02.2017).

20 Ишлаев В. Почему бы не сделать так? // Северный комсомолец. Архангельск. 1956. 30 нояб.

21 Козлов Д. С. Общественные инициативы архангельской молодежи в годы «оттепели» // Вестник Северного (Арктического) федерального университета. 2012. № 5. С. 11.

22 Государственный архив социально-политической истории Тюменской области (далее - ГАСПИТО). Ф.1444. Оп. 19. Д. 43.

23 Записано автором настоящей статьи 20 августа 1982 г.

24 Постановление ЦК ВЛКСМ от 21 апреля 1955 г. «О работе газеты “Сталинское племя” - орган ЦК ЛКСМ Украины» // Сборник постановлений ЦК ВЛКСМ (принятых после ХІІ съезда ВЛКСМ). С. 206-207.

25 Ванин В.А. Комсомол середины 1950-х гг.: внутренняя жизнь и реализация воспитательной функции (на материалах Тамбовской области): дис. ... канд. ист. наук. Тамбов, 2013. C. 49 .

26 ГАСПИТО. Ф.П-1184. Оп. 1. Д. 1373 а. Л.59.

27 Постановление ЦК ВЛКСМ от 30 мая 1955 г. «О работе газеты "Пионерская правда"» // Сборник постановлений ЦК ВЛКСМ (принятых после ХІІ съезда ВЛКСМ). С. 214.

28 Там же. С. 214-215.

29 Там же. С. 215.

30 Там же. С. 217.

31 Уль $K$. Поколение между «героическим прошлым» и «светлым будущим»: роль молодежи во время «оттепели» // Антропологический форум. 2011. № 15. С. 284.

32 РГАСПИ. Ф.М-16. Оп. 13. Д. 57. Л. 15.

33 Хрущев Н. С. За тесную связь литературы и искусства с жизнью народа. М., 1957. С. 23.

34 Правда. 1959. 18 нояб.

35 Беляев В.А. Отечественная интеллигенция как объект и субъект политики. Казань, 2006. C. 27.

36 ГАСПИТО. Ф.П-1045. ОП. 1. Д. 10972. Л. 25.

37 Сборник постановлений ЦК ВЛКСМ (январь 1958 г. - январь 1960 г.). М., 1960. C. 226-230.

38 Там же. С. 227.

39 Об идейно-порочной повести А. Кулаковского «Дабрасельцы», опубликованной в журнале «Маладосцъ» (орган ЦК ЛКСМ Белоруссии и Союза писателей БССР) // Там же. С.260-261.

40 Об ошибке редакции журнала «Пионер», опубликовавшей низкую в идейно-художе- 
ственном отношении комедию Ю. Сотника «Старая керосинка» // Там же. С. 396.

41 Постановление ЦК ВЛКСМ от 28 апреля 1959 г. «О работе журнала "Молодой колхозник”» // Там же. С. 399.

42 РГАСПИ. Ф.М-6. Оп. 14. Д. 111. Л. 38.

43 Постановление ЦК ВЛКСМ от 26 сентября 1960 г. «О грубых ошибках журнала "Смена”» // Сборник постановлений ЦК ВЛКСМ (январь - декабрь 1960 года). М., 1961. С. 369.

44 Там же. С. 367.

45 Смена. 1960. № 17. С. 24.

46 След на земле. Т. 8. 100 лет вместе с Нижним Тагилом: в честь юбилея старейшей газеты города. Нижний Тагил, 2006. С. 120-121.

47 Сборник постановлений ЦК ВЛКСМ (январь 1958 г. - январь 1960 г.). С. 235.

48 Архивная история газеты «Тюменский комсомолец». URL: http://media.utmn.ru/library_ view_book.php?chapter_num=26\&bid=840 (дата обращения: 02.02.2017).

49 ГАСПИТО. Ф.П-1184. Оп. 1. Д. 1373 а. Л. 57.

50 Сборник постановлений ЦК ВЛКСМ (январь - декабрь 1960 г.). С. 287.

51 Там же. С. 291.

52 Там же.

53 Даутова Р.В. Хрущевская «оттепель»: журналисты как представители российской интеллигенции и власть // Информационное поле современной России: практики и эффекты. Казань, 2008. С. 42.

54 Сборник постановлений ЦК ВЛКСМ (январь - декабрь 1960 г.). С. 293.

55 Семичастный B. Незабываемое // Никита Сергеевич Хрущев: материалы к биографиии. М., 1989. С. 49.

56 Стровский Д.Л. Отечественная журналистика новейшего периода. М., 2012. С. 176.

57 Юность. 1958. № 3. С. 112.

58 Юность. 1958. № 7. С. 102-103; № 11. С. 102-106.

59 Цит. по: Друзенко А. Прощаясь с Аджубеем // Известия. 1993. 24 марта.

60 Подробнее см.: Грушин Б.: 1) Институт «общественного мнения "Комсомольской правды”» // Мониторинг общественного мнения: экономические и социальные перемены. 2003. № 1. С. 60-74; 2) Четыре жизни России в зеркале опросов общественного мнения. Очерки массового сознания россиян времен Хрущева, Брежнева, Горбачева и Ельцина: в 4 кн. Жизнь 1-я. Эпоха Хрущева. М., 2001.

61 Комсомольская правда. 1960. 16 мая.

62 Лобанов К. Комсомол Кузбасса в годы «оттепели». URL: http://vkomsomole.ru/news/394komsomol-kuzbassa-v-gody-ottepeli (дата обращения: 07.08.2016).

63 Сборник постановлений ЦК ВЛКСМ (январь - декабрь 1960 г.). С. 143.

64 ГАСПИТО. Ф.П-1184. Оп. 1. Д. 1377. Л. 84-85.

65 Сборник постановлений ЦК ВЛКСМ (январь - декабрь 1960 г.). С. 146-147.

66 Там же. С. 148-149.

67 Савенко E. Н. Литературный самиздат Сибири второй половины 50-х - начала 80-х гг. XX в. // Гуманитарные науки в Сибири. 2006. № 3. С. 34.

68 ГАСПИТО. Ф.П-1184. Оп. 1. Д. 1314. Л. 10.

\section{ДЛЯ ЦИТИРОВАНИЯ}

Слезин А. А. Комсомол и молодежная печать в период ранней «оттепели» // Новейшая история России. 2017. № 4 (21). С. 133-147.

УДК 316.323 .72

Аннотация: Предметом исследования в статье является стиль взаимоотношений комсомола и молодежных печатных изданий в середине и конце 1950-х гг. Основные группы источников составили архивные документы, в первую очередь документы Российского государственного архива социально-политической истории (РГАСПИ) и Государственного архива социально-политической истории 
Тамбовской области (ГАСПИТО), а также публикации периодической печати 1950-х гг. Комсомол рассматривается как социокультурный феномен. Деятельность комсомола оценивается преимущественно с государственных и общечеловеческих позиций. Для объективной оценки последствий деятельности комсомола большое значение имело признание основ концепции воспитания жизнеспособных поколений И. М. Ильинского. Проанализировав решения центральныхи региональных органов ВЛКСМ, автор приходит к выводу о сдерживании комсомолом процесса расширения гласности. Вместе с тем показано, что ВЛКСМ активно привлекал к работе в средствах массовой информации молодые кадры, способствовал развитию юнкоровского движения, стенной печати, внедрению новаторских подходов к формированию содержания газет и журналов, вниманию СмИ к юношеским интересам. Показано влияние комсомола на становление самиздата. Большое внимание уделено этическим принципам советской молодежной журналистики: пониманию «правдивости», осуждению методов фальсификации, росту внимания к интересам личности, выдвижению на первый план темы маленького человека гражданина. Выявлены стремления молодежной печати точнее отражать реалии повседневной жизни, демонстрировать проблемные подходы к восприятию действительности. Показано, что комсомол призывал к развитию критики и самокритики, но при этом выступал против смакования недостатков, оскорбительного тона публикаций. Многое делалось для обсуждения наиболее принципиальных материалов печати и принятия практических мер по устранению вскрытых в печати недостатков.

Ключевые слова: молодежь, комсомол, пионеры, газеты, журналы, политическая культура, оттепель, печать.

Сведения об авторе: Слезин А. А. - доктор исторических наук, профессор, Тамбовский государственный технический университет (Тамбов, Россия); anatoly.slezin@yandex.ru

\section{FOR CITATION}

Slezin A. A. Komsomol and Youth Press during the Early "Thaw", Modern History of Russia, no. 4, 2017, pp. 133-147.

Abstract: The subject of the research is the relationship between the Komsomol and youth publications in the middle and in late $1950^{\text {th }}$. The main sources of information were based on the archives, mainly The Russian State Archive of Socio-Political History (RGASPI). And the Russian State Archive of Socio-Political History of the Tambov region (GASPITO), along with periodical publications of the 1950s. Komsomol is seen as a social and cultural phenomenon. Komsomol actions are predominantly evaluated from pan-human and national viewpoints. For the objective estimation of the consequences of Komsomol's activities it was important to admit the basics of llinsky's concept of bringing up healthy generations. After the analysis of the decisions of the central and regional All-Union Leninist Young Communist League (AULYCL) agencies, the author comes to the conclusion that the Komsomol was restraining the process of expanding public openness. Alongside this, the AULYCL was recruiting young people to work in the sphere of Mass media, helping develop cub reporters' movement, bulletin boards, as well as implementing innovative approaches to moulding magazine and newspaper contents, and drawing the Mass media attention to young people's needs. A lot of attention has been centered around understanding the ethical principles of the Soviet youth journalism and the term "truthfulness", criticizing methods of adulteration, exploring the sphere of personal interests and highlighting the theme of a small human and a citizen. The author also identifies certain youth publishing intentions depicting the realities of everyday life more precisely and demonstrating the problem of approaches to the perception of reality. It has been shown that the Komsomol advocated for the development of criticism and self-criticism, but at the same time did not favor discussing weak points and issuing offensive publications. A lot was dedicated to discussing essential printing materials and making arrangements for eliminating evident problems.

Keywords: youth, Komsomol, Pioneers, newspapers, magazines, political culture, Thaw, press.

Author: Slezin A. A. - Doctor of History, Professor, Tambov State Technical University (Tambov, Russia); anatoly.slezin@yandex.ru 


\section{References:}

Belyaev V. A. Otechestvennaya intelligenciya kak obiekt i subiekt politiki (Kazan, 2006).

Dautova R. V. 'Khrushchevskaya "ottepel”: zhurnalisty kak predstaviteli rossijskoj intelligencii i vlast', Informacionnoe pole sovremennoj Rossii: praktiki i ehffekty (Kazan, 2008).

Drilenko V. V. 'Molodezh Khabarovskogo kraya i vlast v period "ottepeli" 1953-1964 gg.' Gumanitarnye i socialnye nauki, no. 2, 2010.

Grushin B. 'Institut obshchestvennogo mneniya "Komsomolskoy pravdy"', Monitoring obshchestvennogo mneniya: ekonomicheskie i socialnye peremeny, no. 1, 2003.

Grushin B. Chetyre zhizni Rossii v zerkale oprosov obshchestvennogo mneniya: ocherki massovogo soznaniya rossiyan vremen Khrushcheva, Brezhneva, Gorbacheva i Eltsina, 4 vols (Moscow, 2001).

Korneva L. E. Obshchestvenno-politicheskaya i kulturnaya zhizn Zapadnoj Sibiri v 1953-1964 gg. i ee otrazhenie $v$ periodicheskoj pechati [Candidate of History Dissertation] (Tomsk, 2006 ).

Kozlov D. S. 'Obshchestvennye iniciativy arhangelskoy molodezhi v gody "ottepeli"', Vestnik Severnogo (Arkticheskogo) federalnogo universiteta, no. 5, 2012.

Kuznetsov V. V. Rol pechati v organizacii osvoeniya celinnykh i zalezhnykh zemel na Altae, 1954-1960 gg. [Candidate of History Dissertation] (Kemerovo, 2000).

Savenko E. N. 'Literaturnyi samizdat Sibiri vtoroj poloviny 50-h - nachala 80-h gg. XX v.', Gumanitarnye nauki $v$ Sibiri, no. 3, 2006.

Semichastnyi V. Nezabyvaemoe. Nikita Sergeevich Khrushchev: materialy k biografii (Moscow, 1989).

Skorochkin R.V. Mestnaya pechat' v SSSR 1953-1957 gg. na materialakh Tambovskoj oblasti [Candidate of History Dissertation] (Tambov, 2006).

Sled na zemle, Vol. 8: 100 let vmeste s Nizhnim Tagilom: V chest' yubileya starejshej gazety goroda (Nizhniy Tagil, 2006).

Strovskiy D. L. Otechestvennaya zhurnalistika novejshego perioda (Moscow, 2012).

Uhl K. 'Pokolenie mezhdu "geroicheskim proshlym" i "svetlym budushchim": rol molodezhi vo vremya "ottepeli"', Antropologicheskiy forum, no. 15, 2011.

Vanin V. A. Komsomol serediny 1950-kh gg.: vnutrennyaya zhizn i realizaciya vospitatelnoj funkcii (na materialakh Tambovskoj oblasti) [Candidate of History Dissertation] (Tambov, 2013). 